\title{
Seeking Refuge in an Unrecognized State: Oromos in Somaliland
}

\author{
AnNa Lindley
}

\begin{abstract}
The self-declared state of Somaliland is much better known as a refugee producing territory than a refugee destination. Yet in recent years the territory has witnessed growing nonSomali immigration from the Oromo regions of Ethiopia. In the wake of marginalization and oppression in Ethiopia, these newcomers find a precarious refuge in Somaliland, demonstrating some of the challenges of in-region protection and integration in the Horn of Africa.
\end{abstract}

\section{Résumé}

L'État non reconnu mondialement $d u$ Somaliland est mieux connu comme territoire producteur de réfugiés que destination pour ceux-ci. Pourtant, le Somaliland a $v u$ ces dernières années une augmentation d'immigrants non somaliens provenant de l'Oromie en Éthiopie. Dans le sillage de leur marginalisation et oppression en Éthiopie, ces nouveaux arrivants trouvent un refuge précaire en Somaliland, démontrant certains des défis de la protection à l'intérieur de la région et de l'intégration dans la Corne de l'Afrique.

S omaliland, the de facto state on the northern periphery of the Horn of Africa, is best known as the site of mass emigration as a result of political oppression and civil war. In recent years, however, the territory has witnessed growing immigration. A significant proportion of Somaliland's migrant population originate not from war-torn southern Somalia, but rather from various parts of Ethiopia. While an Ethiopian presence is not a new phenomenon it has been increasingly noticeable in recent years as Somaliland has stabilized. Some of these immigrants work in Somaliland's capital, Hargeisa, for the Ethiopian mission, businesses, or NGOs, and some fled to Somaliland since 2007 in the wake of the Ethiopian government's brutal counter-insurgency campaign in the Ogaden region. This account, however, focuses on a third group, exploring the fortunes of people of Oromo origin living in Somaliland. The Oromo are the largest ethnic group in Ethiopia, but have found themselves marginalized from power under successive regimes, most recently by the Ethiopian People's Revolutionary Democratic Front (EPRDF), which came to power following the 1991 revolution which brought down the authoritarian Derg regime. Political and economic oppression in the Oromia region, following the withdrawal of the Oromo Liberation Front (OLF) from the Transitional Government of Ethiopia in 1992, have forced unknown numbers to leave the country.

Most research in the last twenty years on Ethiopian refugees has focused on large refugee camp populations in Djibouti, Sudan, and Kenya and the major resettled populations in North America and Europe. There is a dearth of information on the situation of the many Oromos living in the Somali regions. Indeed, for outsiders, it is often hard to believe that anyone would seek refuge in the Somali territories, which in the last two decades have been much better known for producing than hosting refugees. Their presence has recently been brought to international attention as a result of transit migration and boat smuggling to Yemenalthough many are not in transit, but have been living in the Somali regions for several years. Recent research by the Refugee Studies Centre, Oxford University ${ }^{1}$ in Hargeisa, Somaliland, offers some insights into the situation of this population and the challenges they face, drawing on twelve individual interviews and group discussions with some twenty-five people, carried out with the help of two Oromospeaking research assistants in July 2008, as well as consultations with NGO workers, UNHCR, government officials, business people, and other local residents. 


\section{Causes of Migration}

Despite initial high hopes, ethnic federalism initiated by the EPRDF is now thought by some analysts to have failed to accommodate grievances, while promoting ethnic-self awareness among all groups of Ethiopians. ${ }^{2}$ According to Oromo research participants, their problems in fact escalated following the 1991 revolution. Most directly, they described a climate of fear and repression, claiming that the government and regional authorities used accusations of links to the OLF to justify a range of repressive measures, including extrajudicial killings, detentions without trial, and harassment of people publicly expressing criticism of government policies and of their families. ${ }^{3}$ A minority of our research participants volunteered the information that they had supported the OLF concretely in some way, and many more said that more broadly there was considerable resentment and politicization among their communities as a result of their treatment at the hands of the authorities.

The research participants also described other treatment by state officials that they saw as intended to disempower their communities. Among them were people of poor as well as relatively prosperous backgrounds, and they had previously engaged in a range of occupations-working as traders, farmers, herders, students, and casual labourers. They emphasized the natural wealth of the areas they live in, but were frustrated by what they saw as undermining economic measures, such as the debt relations resulting from the distribution of fertilizers on credit by local officials and the selective authorization and withholding of trading licences. The prohibition on using the Oromo language in many areas of public life was lifted by the EPRDF, but participants asserted that the repressive political climate and the introduction of new and intrusive local institutions (supposedly as a means of promoting community development) had deliberately disrupted patterns of trust and mutual support in their communities.

Various factors triggered the departure of those interviewed. Most had left in the run-up to the 2005 elections and since, when there was a surge in Oromo arrivals in Somaliland. Many cited examples of close relatives who had been killed or imprisoned. Many had been imprisoned themselves, and subjected to torture and inhuman treatment. A significant proportion had been high school or university students and had been caught up in the waves of surveillance, expulsions, and arrests that followed various student demonstrations. The general pattern was that they had left alone, secretly, and often precipitously-following detention, a traumatic event, or threat from officials-with the primary aim of getting out of Ethiopia. Most said that they had come to Somaliland simply because it was close, without knowing much about the situation there. This picture contrasts with the commonly held view in Somaliland that the Oromos are economic migrants. Reportedly some people from Oromia do travel to Somaliland primarily to work for a few months or years, but none of the people participating in this research said that they had left Ethiopia to find work. Rather they emphasized that they had reluctantly left behind families, fertile lands, university careers, or business interests, in the face of what they felt was considerable personal danger, for an economically dismal existence in Somaliland.

\section{Situations in Somaliland}

People originating from the Oromo region are generally among the poorest of poor in Somaliland. They are effectively restricted to the worst-paid jobs, jobs which Somalilanders find demeaning, such as rubbish collection, toilet digging and emptying, clothes washing, and other casual work. They are criticized for begging with their children, something seen by locals as alien and shameful. Some are able to find work as watchmen but generally on lower pay than locals. Stories of abusive employers abound: most commonly, research participants reported problems with getting paid for work they had done, some saying that their employer threatened to report them to the Ethiopian mission and the Somaliland criminal investigation department to make them give up for fear of deportation.

Community relations are generally rather segregated, due to the language barrier, distinct culture, and belief among many locals that the Oromos are Christian (although many coming to Somaliland are in fact Muslim). As non-Somalis, they fall outside the Somali clan arbitration system, and have struggled to resolve disputes with members of the host community. Recognizing the way things work locally, a committee of Oromo elders was established, with the approval of the Ministry for the Interior, to try to represent their interests, but has struggled to be taken seriously by Somali elders. The suicide bombings of the Ethiopian mission, United Nations Development Programme offices, and the Presidential Palace, and a subsequent backlash against "foreigners," including Oromos, in Somaliland, did not make things any easier.

\section{A Precarious Refuge?}

Somaliland itself has undergone massive political upheaval in the last thirty years. Growing resistance to Siyad Barre's regime culminated in the civil war of 1988-1991. During the 1990s, despite a relapse to conflict mid-decade, a political system was gradually established that has since ensured stability and peace. But the Somaliland government has not been recognized internationally, and has recently come under major political strain regarding disagreements over the much-delayed presidential elections. Oromo research 
participants emphasized the poverty of Somaliland-one describing the position of immigrants as: "It is like leading the life of a watchman of another watchman."

Nevertheless, legally speaking, insofar as it governs the population in areas where it has effective control, the Somaliland government is bound by customary international human rights law. ${ }^{4}$ Moreover, under Article 10 of its constitution, Somaliland has committed to international obligations entered into by the Republic of Somalia, including the 1951 and 1969 Refugee Conventions. Specifically, Article 35(1) of the Somaliland constitution specifically grants foreign citizens the right to seek political asylum.

An asylum system has been established, administered by a Refugee Eligibility Committee under the Ministry of the Interior, working in co-operation with UNHCR. All this is rather remarkable progress, given the precarious political and economic situation of Somaliland. However, early reports of corruption and lack of capacity led to the suspension of registration (with the interim measure of large-scale registration exercises) pending an overhaul of the system, which reopened in 2008. In 2008, Somaliland had some six thousand registered asylum seekers and well over one thousand recognized refugees, mainly Ethiopian Oromos. Refugees were given a recognition letter and were able to claim a US $\$ 50$ allowance each month from UNHCR. For reasons already mentioned, the prospects for local integration are deemed slim and some have been resettled in third countries. But a large proportion of Oromos in Somaliland are not registered as asylum seekers, either because they simply want to work, or through fear, poverty, or ignorance.

However, the protection of Ethiopian nationals seeking refuge in Somaliland is at best patchy. There have been numerous reports of deportations or attempted deportations of Ethiopians from Somaliland, including some of our Oromo research participants and people they had known personally. ${ }^{5}$ Many of the participants lived in fear of deportation, and several explained that they moved frequently around the city to avoid detection. According to international conventions which Somaliland has committed to honour, asylum seekers and refugees should be protected from return to a country where their life or freedom may be threatened. Moreover, according to Article 35(3) of the constitution, foreign citizens in general can only be extradited where a formal extradition treaty exists: according to Human Rights Watch no such treaty can exist with Ethiopia, as it does not recognize Somaliland's independence. ${ }^{6}$ However, the Somaliland authorities can come under considerable political pressure to be co-operative, or at least not obstructive: Ethiopia is the regional superpower and Somaliland's major regional ally, and the government is highly dependent on revenue from Berbera Port and the trade corridor into Ethiopia.
It is hard for many Oromos in Somaliland to access any kind of assistance. Compatriots are sometimes able to offer some help, but they are generally struggling to survive themselves. NGOs are generally not particularly interested in assisting non-Somalis, given the major issues facing many local people. As one interviewee put it, "There are many NGOs in this country. But it is impossible to approach them because the local community won't allow you. You have to pass many hedges to get them." In this context, the UNHCR, the Refugee Welfare Centre (run by Save the Children and funded by UNHCR), the Refugee Committee, and the Hargeisa University Legal Clinic (funded by UNDP) provide crucial if limited support. More generally, the International Organization for Migration (IOM) has been trying to sensitize local communities to the rights and needs of migrants, particularly those on the move through Somaliland.

With problems in Ethiopia ongoing, and many lacking the funds to move any further than Somaliland, the Oromo presence in Somaliland is likely to continue. There are children born in dire poverty to Oromo parents, who are unlikely to "return" to Ethiopia. While many in Somaliland may not yet be willing to contemplate the idea, alongside the territory's many other challenges, people of Oromo origin are likely to continue to form a permanent minority in Somaliland in the long run, and deserve to live in dignity.

\section{Notes}

1. This research was conducted as part of a wider project on migration in the Somali regions; see http://www.rsc.ox.ac. uk/research_current_rz5.html and http://www.microconflict.eu.

2. International Crisis Group, Ethiopia: Ethnic Federalism and its Discontents. Africa Report No. 153. (Nairobi and Brussels: International Crisis Group, 2009).

3. See also Human Rights Watch, Suppressing Dissent: Human Rights Abuses and Political Repression in Ethiopia's Oromo Region (New York: Human Rights Watch, 2005).

4. See Human Rights Watch, "Hostages to Peace" Threats to Human Rights and Democracy in Somaliland (New York: Human Rights Watch, 2009).

5. See also Human Rights Watch, "Hostages to Peace"; also Amnesty, Human Rights Challenges: Somaliland Facing Elections (London: Amnesty, 2009).

6. See Human Rights Watch, "Hostages to Peace."

Anna Lindley is a lecturer in the Department of Development Studies at the School of Oriental and African Studies, University of London, specializing in migration issues.

The author is grateful to those who assisted with the research, in particular Murad Juneydi. 